\title{
Political Philosophy in the Biography of Han Poetry
}

\author{
Qiao Dongxue \\ China JiLiang University
}

\begin{abstract}
At the beginning of the Han Dynasty, the parallel political ideology of Confucianism and Law also occupied the mainstream. The rule of rites and the rule of law complement each other and do not independent of each other. In the Western Han Dynasty, Han Ying, as a great scholar, advocated the rituals of Chongli (worship ceremony) and absorbed the rule of law of Legalists. This mixture is reflected in his main work, Han Shi Wai Zhuan. The purpose of this paper is to explore and think the unified thought of ritual and law in the "Han Poetry", which makes the study of the thought of rites and law more complete and mature in Han Ying and even in the early Han Dynasty.
\end{abstract}

Keywords_"Han Shi Wai Zhuan"; "Rite"; "Law"; "Management"

\section{INTRODUCTION}

Since the Han Dynasty, the political ideology of Confucianism and Legalism was almost adopted by rulers of the past dynasties. However, regardless of the rule of rites and the rule of law who occupies the upper hand, they can not completely escape from each other, or take the rule of ritual and rule of virtue as the dominant, supplemented by the rule of law, or take the rule of law as the dominant, and supplemented by moral education. The expression and interpretation of the thought of ritual governance has become an important issue facing the modern Confucian classics in the Han Dynasty. Han Ying, a representative of the Western Han Dynasty, was a representative of the modern literary classics. In his life in Chongli, he advocated courtesy and courtesy. From the angle of secular human feelings, the ceremony was linked to people's life. As one of the means to realize the rule of the king, Han Ying has absorbed the legalist rule of law, advocating the correction of ritual and laying equal stress on etiquette and law. The courtesy and the law are interdependent and interdependent. The basic structure of the political theory is constructed from two aspects of moral norms and system decrees to guarantee the orderly operation of the country.

\section{THE TREATMENT OF "RITES" IN THE "BIOGRAPHY OF HAN POETRY"}

Confucius and Mencius have different ways of "rite", which is different from the "benevolence" of moral emotion. Han Ying's ritual is greatly influenced by Xunzi. In Han Shi Wai Zhuan, the origin of Han Ying's etiquette is quite similar to Xunzi's understanding of rites. In Xunzi's view, human nature is evil. In order to control human desires and avoid the emergence of disorderly society, such as grabbing and robbing of human nature, Xunzi put forward the idea of the rule of rites.
"Nature" is mainly expressed as "desire". If it is obedient to human nature and indulge the people's desire, it will lead to the "disorderly ceremony" and the behavior of destroying the social order. It is necessary to make use of courtesy to make people get rid of evil and do good and avoid social disorder. Xunzi thought that the ritual was born in the "false of the sage", and the sage "set up the ritual and righteousness, and make the law, in order to pretence the human nature and correct it. It is out of the rule that the man is in the way of the Tao ("Xunzi sexual evil"), the saint in the way of etiquette and righteousness, guide people to abandon evil to the good, so that it is consistent with the rule of rites and righteousness. Han Ying inherited Xunzi's viewpoint that "rites arise from desire", "raising people's desire and giving people", and further put forward the view of "being in love with desire".

Both Han Ying and Xunzi respected the rites, and the implementation of the rule of rites was regarded as the basis of political affairs. Unlike Xunzi, Han and baby linked courtesy with love, and the relationship between rites and rites advocated by him was satisfactorily explained through the intermediary of "love", which gave the rites more human color. Love is sincere from the heart, and this kind of reasonable and moderate love is righteousness. It is a courtesy to show such benevolence and righteousness in a respectful way. To treat others with courtesy is called Rong, and a beautiful gift can be used to cultivate one's moral character. Here, Han baby directly gives love to benevolence and puts forward the proposition of "love from emotion", which is mainly expressed in Confucius as a kind of generalizing moral sentiments, and $\mathrm{Fu}$ with specific emotional connotation, making it a moral character with practical content. Compared with his former thinker, this is a progress in the history of thought. Han Ying put benevolence, righteousness, courtesy and put forward, and emphasized his educational role again and again. It was thought that both rites and righteousness were determined by love. This is the same as the book of Rites: "the gentleman is in the courtesy, and there is an exhaustion of emotion and caution". From the angle of secular human feelings, Han Ying cleverly links ceremony with people's life, and explains the commonality of the two, thus providing a broad social basis for the application of rites. In the Western Han Dynasty, the rule of Confucianism was respected by the rulers of the Western Han Dynasty. In the context of the ideology of the state, the relationship between the Korean and the children was straightened out, which made it easier for people to accept the etiquette, which was of great benefit to the spread of Confucianism. 


\section{A. The role of "rite" in political life}

In the core spirit of political thought, Han Yingji attached importance to propriety. The meaning of "Han Shi Wai Zhuan" is rich and varied. Han Ying first expounded the fundamental role of $\mathrm{Li}$ in political life from the perspective of founding a nation. In the opening of the "foreign biography", Han baby was forthcoming with the Japanese and the moon. The fifth chapters of the outer biography raised the etiquette and meaning to the height of the rise and fall of the state. As the fundamental rule of the world, it was not only the general principle of building fame, but also the fundamental of the national prosperity. In Han Ying's opinion, little to personal accomplishment, things to do, to the political state, all need to be courtesy can be accomplished. Propriety is not only the foundation of self-cultivation, but also the key to governing a country. Courtesy means the determination of political order and ceremony and abolition, which determines the success or failure of the rise and fall of the country's politics. Therefore, Han and infant clearly mean from the son of heaven and even the princes, the doctors and the people. They do not obey the ceremony, and put forward Chongli and rite to all the social groups of the supreme ruler to the common people.

\section{B. The regulating function of "rite"}

"Biography" regards etiquette as a system standard to regulate material conflicts. The "biography" inherited the view that Xunzi took the etiquette and meaning as "the affectation of human feelings" ("Xunzi sexual evil"), and recognized the legitimacy and rationality of "love" and "desire".

According to the biography, the six nature of human feelings is the natural revelation of human nature. In order to educate the people and govern the country and the people, the king of Kings tempered his six desires and restrained his desires in accordance with the rites and righteousness, giving moral education to the common people. In Han Ying's view, etiquette and righteousness are more important than material conditions, so he advocates people's Chongli and ritual. However, in Han Ying's view, the Enlightenment of the etiquette and meaning is a prerequisite. The five chapter of the book of outer biography points out that before the enlightenment, it is necessary to make the people rich and secure the people, to satisfy the basic needs of the people for the basic life of the food and warm clothes. Han Ying, a courtesy view of courtesy and courtesy, combines love and ritual with each other, meets the common people's rational pursuit of material needs, solves the conflicts and contradictions between the basic needs of people and the social order, and makes both the two stalemate and further strengthen the guidance of the social order.

\section{C. "Rite" is a moral criterion}

As one of the important categories of Confucian ethics, ritual is a moral criterion regulating ethical order. In order to realize the national security of the state, in addition to the legal, political and other institutional constraints, we must rely on the moral standards of rites to regulate the order of human ethics, adjust the relationship between the individual and the society, and realize the harmonious and orderly society. As a standard and moral criterion for standardizing people's behavior, ritual regulates the basic connotation of the personality of the gentleman. In this regard, Han and infant emphasize the significance of the rites from three aspects of benevolence, loyalty and faith.

"Foreign" thinks that benevolence, loyalty and letter are one of the important manifestations of rites. If one violates these three basic moral standards, they will ignore parents, betrayal monarchs, cheat friends, this kind of behavior is not the proper meaning of the gentleman's personality, but more difficult to call it man. To illustrate this point, he quotes the poems in Book of Songs at the end, emphasizing the importance of ritual as a criterion for judging the suitability of moral behavior. In terms of the specific connotation of ritual, Han Ying's ritual mainly refers to the Confucian doctrine of "five constant". He inherited the traditional Confucian moral concepts of benevolence, righteousness, gift, wisdom, filial piety, fraternity, loyalty, faith and so on, and used it as the principle of dealing with all ethical principles, such as monarch, father, son, brother and husband and wife. All of them do their duty conscientious, and realize the mutual trust and friendly harmonious situation between people and people. From the point of view of morality, Korean and baby put forward corresponding ethical requirements for all social classes. The "biography" points out the basic principles that people should follow in political life, social life and family life. It emphasizes that all kinds of moral and ethical relations should follow the rules of rites, including the courtesy of the king, the king of the minister and the loyalty. Filial piety, brother and friend, husband and wife, so as to regulate the behavior of the members of the society, so that the host and the people, individuals and social groups can be standardized and orderly, together.

Like other statesmen and scholars in the early Western Han Dynasty, Han Shi Wai Zhuan also reflects the positive tendency of using the world. It tries to realize the attack and chaos of the tyrannical rule of the Qin Dynasty by respecting the ceremony and the way of Chongli. This is also the common aspiration of the Confucian intellectuals in the early Han Dynasty. From the angle of respecting the rites and Chongli, the "external biography" criticized the cruel torture of the Qin Dynasty fiercely. Han Ying pointed out that the rule of law of the rulers of the Qin Dynasty was too overbearing, which led to the perdition of the two generation of States, which was caused by the abandonment of the policy of the Confucianists to govern the country by the country and to govern the world by the king. In the course of reflection on the historical lessons of the death of the Qin Dynasty, Han Ying realized that the monarchy must adhere to righteousness, follow the rites, and take the etiquette and meaning as the basic criterion for regulating the morality and regulating the social order. In order to satisfy the basic needs of the people, we should follow the path of the king of kings and educate the people with etiquette and music, so as to raise the level of moral cultivation of the whole society. Han Ying Li tried to bring order back to the Qin Dynasty through the concept of Chongli Suntech and courtesy, and strengthened the political guidance of the early Han Dynasty. 


\section{THE IMPORTANCE OF "LAW" IN HAN SHI WAI ZHUAN}

While emphasizing the rule of propriety and justice, Han Ying also paid special attention to legalist rule of law. Han Ying believes that ritual and law are the two means to realize the government of the king. On the basis of Confucianism as the main body, it is the basic principle and effective means to govern the nation and the people.

Han Ying attached great importance to the legalist school thought. He strongly advocated the correct method of ritual, laying equal stress on etiquette and law, and combining etiquette and law as the basic means of administration. "Biography" clearly pointed out that governing the country needs Confucianism's positive action, saving the world from the integrity and integrity of the Legalists, and is the combination of benevolence and law. Han Ying believed that honest, honest, impartial, and righteous spirit is essential for governing the country.

"Foreign" believes that the ultimate completion of the benevolent political royal road can not be separated from the hegemonic method of loving the people, advocating the combination of the law of etiquette and the law of King hegemony and using it, saying that the principle of the ruler of a country is to rule the government at the upper end of the court It is necessary to restrict the words and deeds of the subjects according to the law and the value and accuracy of the people, Nakaki Tachitadanobu and the people. It is necessary to start from the rule of the ruler, so that the people can achieve social stability and order. Under the joint action of the concept of etiquette and law, "biography" emphasizes that the key to upholding the rule of law is to govern officials, and secondly to govern the people. As a forceful executive of the state's political opinions, officials' words and deeds are directly related to the implementation and implementation of decrees. If a monarch has bad officials when he hesitates, he will not be punished in time. It is easy to create a big disaster and endanger the stability of state power. For those who are good at usage, courtesy and behavior, the "biography" has also been appreciated. The three chapter of the book of outer biography compares Ji Sun and Shi Zhilu with Zheng Zheng, pointing out that the former lacks the heart of modesty and respect for the people. The latter. In the ten and second chapters of "biography" volume, Zhong Zhong Qi Qi discussed in detail and praised the way of governing the country. In addition to the strict legal requirements for the upper master, the implementation of the "foreign biography" is more dependent on the law. The "Tao" here is the way to follow the ceremony, which includes the etiquette and the meaning of the ritual and the five Chang. It is necessary to follow the courtesy to give full play to its effect, because Tao is the way and law that can be carried out smoothly. If the penalty is biased, it will lead to chaos. Then, it enumerates many examples in history, which show that the way of doing things is more acceptable than that of high cities and deep prosperity.

The emphasis on the role of courtesy is to restrict the norms of the behavior of the members of the society. It is the moral self-discipline that guarantees the impartiality of the impartiality of the person and the minister, that is, the use of benevolence must be the starting point. In personal terms, the etiquette and etiquette play a role in the heart, the ritual is guided inside, the law is standardized outside, and the two are equal and unbiased in order to better realize the management of the country and the norms of the social subject. For the whole of the society, the law can not be alone or abused. The tenth chapter of "foreign biography" thinks that the law is based on sincere love and is close to the aspect of courtesy.

\section{CONCLUSION}

The propositions of the positive law advocated by the "foreign biography" are the precondition of the ritual as the precondition of the positive law, the system guarantee of the correct law, the interdependence of the rites and the law, and the interdependence of the law, and the guarantee of the orderly operation of the state from two aspects of moral norms and system decrees. As the two important means to govern the country, the courtesy leads to the inside, the law is standardized outside, the law is on the road, the way is the direction, the law according to the rite way is done, the law is discarded by the way of courtesy. However, it has to be noted that ritual and law are only one of the important ways to realize the peace and peace of the people in the world. The core of the political politics is to love the people and do the benevolence and righteousness.

\section{REFERENCES}

[1] [Han] Han Ying. Han Shi Wai Huan [M]. Taiwan: Taiwan Commercial Press, 1983

[2] [Qing] Chen Shike Han Shi Wai Zhuan [M]. photocopy Wen Yuan Ge Si Ku Quan Shu.

[3] [Qing] Zhou Tingcai's notes. Han Shi Wai Zhuan preface [M]. Beijing: Commercial Press, 1917.

[4] [Qing] Xu Han, Han Shi Wai school, [M]., Jing Jin Tang series, 1985

[5] [Qing] fan Jia Xiang. Three poems collection: [M]. Shanghai: Commercial Press, 1939.

[6] Zhao Shanyi Han Shi Wai Jian [M]. [M].: Commercial Press, 1978.

[7] Xu Wei Han. Han Shi Wai Jie [M]. [M].: Zhonghua Book Company, 1980.

[8] Wang Sheng min. A new discussion on Han Shi Wai Zhuan, [J]. Journal of Anhui University (zhe Edition), 2003 (2).

[9] Xiao Shiping. A compromise between Meng Xun and Han baby's thought of self-cultivation [J]. Journal of Hebei University, 2004 (1).

[10] Zhang Hongzhen. Han Shi Wai Zhuan Tian Dao Guan [J]. Journal of Linyi Normal University, 2004 (4)

[11] Ma Hongyan. Summary of research on Han Shi Wai Zhuan [J]. Journal of ancient book collation research, 2004 (4).

[12] Yang Liu. Philosophical thoughts on Han Shi Wai Zhuan. [J]. Journal of Guizhou University, 2004 (5).

[13] Zhang Yan. Similarities and differences between Han Shi Wai Zhuan and Analects of Confucius [J]. Journal of Dalian University, 2004 (5)

[14] Ai Chunming. "Han Shi Wai Zhuan" the theory of love and the origin of sexual self proclaimed. [J]. Journal of Northeast Normal University, 2006 (4).

[15] Ai Chunming, Zhou Ying. Interpretation of poetry by Han Shi Wai Zhuan, [J]. Journal of Eastern Liaoning University, 2006 (8).

[16] Ai Chunming. Theory of "Han Shi Wai Zhuan" [J]. Journal of Tonghua Normal University, 2008 (6).

[17] Jin Limin. A study of Han Shi Wai Zhuan. [J]. Heilongjiang history (literature and History), 2009 (6).

[18] Li Junxiu, Han, Meng and Xue: a further discussion on the relationship between Han Shi Wai Zhuan and Meng Xun [J]. Yunmeng journal, 2010 (1).

[19] Wang Yun Fei. On the nature and ideological significance of Han Shi Wai Zhuan. [D]. Hunan: Master's thesis in Classical Philology of Hunan Normal University, 2007.

[20] Xiao Xi Lu Xi Han endowed with the tradition of Poetry: [D]. Hebei: Master's thesis of ancient literature of Hebei Normal University, 2012. 